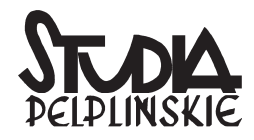 \\ ISSN 0239-4456 \\ eISSN 2391-8713 \\ 53(2019), s. 275-290
}

KS. DAMIAN KUNA

Uniwersytet Mikołaja Kopernika w Toruniu

matatka@interia.pl

ORCID: 0000-0002-3478-3117

\section{WPLYW SPORTU NA ŻYCIE MORALNE CZLOWIEKA - KORZYŚCI, WYNATURZENIA I PRÓBY ICH PRZEZWYCIĘŻANIA W ŚWIETLE NAUKI ŚW. TOMASZA Z AKWINU}

DOI: http://dx.doi.org/10.12775/SPLP.2019.016

\section{Streszczenie}

Niniejszy artykuł jest próbą ukazania wychowawczych aspektów sportu w nauczaniu św. Tomasza z Akwinu. Konieczność tej analizy wynika z wielu przyczyn. Jedną z nich, i bodaj najważniejszą, jest między innymi fakt, że sport początku XXI wieku przestaje być tym, co winno służyć człowiekowi, często stając się zagrożeniem dla życia i godności osoby ludzkiej. Dlatego niniejsza praca ma za zadanie ukazać ogromną potencję i szansę, jaką niesie dla wszechstronnego rozwoju osobowości człowieka uprawianie sportu. W zrozumieniu tego problemu pomocne jest oparcie o naukę św. Tomasza z Akwinu, szczególnie w aspekcie jego spojrzenia na kulturę fizyczną przez pryzmat aretologiczny.

Slowa kluczowe: sport; św. Tomasz z Akwinu; wychowanie; aretologia; kultura fizyczna

Influence of Sport on the Human Moral Life:

its Advantages, its Difficulties and the Efforts to Overcome them according to Saint Thomas Aquinas' Teaching

\section{Summary}

The paper presents the educational aspects of sport in the light of St Thomas Aquinas' teaching. This analysis is very relevant for many reasons. One of them, 
and possibly the most important one, is the fact that in the early $21^{\text {st }}$ century sport ceased to be beneficial to humans and instead it often becomes a threat to our well-being and dignity. Thus the aim of this article is to highlight the huge potential and the opportunities that sport offers to the integrated human personality development. This is made possible by bringing Aquinas' teaching, especially his view on physical culture in the light of aretological primacy.

Keywords: sport; St Thomas Aquinas; education; aretology; physical culture

Sport, jako jedno z najbardziej popularnych zjawisk naszych czasów, wywiera znaczny wpływ na zachowanie ludzi, szczególnie młodzieży. Niestety, obserwując współczesny świat sportu, można mieć niejednokrotnie pejoratywne zdanie na jego temat. Komercjalizacja, doping, chuligaństwo na stadionach i wiele jeszcze innych problemów z tym związanych może budować niechlubny obraz sportu. Niniejszy artykuł ma przekonać czytelnika, że jest to obraz narzucony przez szukające taniej sensacji media, wypaczony, jednostronny, daleki od ideału, jaki przyświeca dobrze rozumianej kulturze fizycznej w ogóle, a sportowi w szczególności. Spróbuję dokonać tego poprzez ukazanie wychowawczych aspektów sportu w oparciu o nauczanie św. Tomasza z Akwinu. Sport jest jedną z tych dziedzin życia człowieka, które w ciągu ostatnich stu lat „zrobiły największą karierę”, jeśli chodzi o postęp, zasięg oraz zaangażowane środki materialne i finansowe. Dlatego też fenomen sportu jest obiektem zainteresowania przedstawicieli różnych dziedzin i dyscyplin naukowych ${ }^{1}$. W tym celu prowadzone są wielokierunkowe i wieloaspektowe badania, które w konsekwencji prawie zawsze zmierzają ku człowiekowi, bowiem on nie tylko jest twórcą sportu, ale także jego podmiotem, odbiorcą i jego celem. Można nawet powiedzieć, że reflektowanie o sporcie jest w jakimś sensie reflektowaniem o człowieku. Jest ono tym bardziej ciekawe i poznawczo pożądane, że właśnie w ramach sportu dokonuje się sprawdzian kondycji ludzkiej, ale nie tylko tej fizycznej i zdrowotnej, także, a może przede wszystkim kulturowej, społecznej, intelektualnej, psychicznej, duchowej i moralnej. $Z$ uwagi na fakt, że wyniki tych sprawdzianów nie zawsze wypadają korzystnie dla samego sportu lub, precyzyjniej, dla ludzi zajmujących się sportem, istnieje potrzeba dokonywania ciągłej refleksji i odkrywania jego humanistycznego zaplecza, powracania do korzeni, do jego realnego lub, dokładniej mówiąc, idealnego archetypu ${ }^{2}$. Co zatem uczynić, aby sport był dziedziną humanistycznego rozwoju człowieka i doskonalenia jego walorów osobowościowych? Sposobem na odwrócenie negatywnych tendencji w świe-

Por. Z. Krawczyk, Sport, w: Encyklopedia kultury polskiej XX wieku. Kultura fizyczna-sport, Instytut Kultury, Warszawa 1997, s. 61-81.

2 Por. Z. Dziubiński, Aretologia sportu, w: Antropologia sportu, red. Z. Dziubiński, SALOS, Warszawa 2002, s. 326. 
cie sportu jest etyczna edukacja, która winna stanowić nierozerwalną całość z procesem sportowego szkolenia. Nieocenioną pomoc na tym polu pozostawił doktor Kościoła Katolickiego - św. Tomasz z Akwinu. Pozostawiony przez niego dorobek aretologiczny obecnie zdaje się zyskiwać na aktualności. Niejednemu sportowcowi w osiągnięciu mistrzostwa i zdobyciu należnej sławy mogą pomóc dobrze wyjaśnione cnoty teologalne, jak również cnoty kardynalne. Natomiast wsparte autorytetem Dekalogu mogą uchronić niejednego przed podejmowaniem niesłusznych decyzji prowadzących do uszczerbku na zdrowiu, zaburzeń psychicznych czy społecznych $^{3}$.

\section{ISTOTA SPORTU}

Wydaje nam się, że wiemy, czym jest sport z historycznego, jak i codziennego doświadczenia, jaką odgrywa rolę i jaki cel mu przyświeca w życiu ludzkim, jak funkcjonuje w świadomości społecznej, jakie pozytywne i negatywne zjawiska mu towarzyszą (np. sprawy dopingu czy ekscesy publiczności na stadionach piłkarskich), na jakie wzloty i upadki jest narażony itp. Na sport można popatrzeć więc naprawdę z bardzo wielu i to najrozmaitszych punktów widzenia: sportowca, trenera, kibica, lekarza, socjologa, psychologa, etyka, teologa itp. I choć niezmiernie ciekawe i nad wyraz potrzebne są badania tych rozmaitych aspektów sportu, to jednak nie pokażą one, czym jest sama jego istota w odniesieniu do człowieka. Dzieje się tak dlatego, że zarówno choćby badania i wyniki tzw. nauk szczegółowych, jak i przede wszystkim potoczne poczynania i sądy ludzkie, ukazują sport tylko i wyłącznie w jego najrozmaitszych objawach, a nie zaś w jego właściwej, „metafizycznej istocie"4.

Wydaje się, że podstawy sportu najlepiej poznać w oparciu o poglądy filozoficzne (metafizyczne) i teologiczne św. Tomasza z Akwinu, który choć żył w średniowieczu i nie znał samego wyrazu ,sport”, i który za przykład sportowca, patrząc na jego obfite kształty namalowane na obrazach i słuchając anegdot dotyczących jego otyłości, uchodzić raczej nie może, to chyba jednak lepiej rozumiał, czym sport jest w swojej pierwotnej istocie, niż niejeden współcześnie żyjący człowiek. Ujmując całościowo naukę św. Tomasza, Artur Andrzejuk, profesor z Uniwersytetu Kardynała Stefana Wyszyńskiego w Warszawie stwierdza, że „sport jest pewnym zespołem odniesień i działań człowieka skierowanym na utrzymanie zdrowia, odpoczynek po pracy, rozrywkę i zabawę, podniesienie ogólnej lub szczegółowej sprawności fizycznej, a niekiedy i psychicznej. Jest więc sport nie-

Por. tamże, s. 349.

4 Por. M. Mylik, Metodologiczne uwagi nad istota i sensem społecznego fenomenu sportu, w: Spoteczny wymiar sportu, red. Z. Dziubiński, SALOS, Warszawa 2003, s. 114. 
wątpliwie pewnym układem relacji”’. Dalej prof. Artur Andrzejuk zwraca uwagę, iż sport może dotyczyć tylko osoby ludzkiej, gdyż odnosi się - najogólniej mówiąc - do ciała człowieka. Wychowanie fizyczne zatem - kierując się do ludzkiego ciała - będąc jednak wychowaniem, stanowi działalność wynikającą z rozumności człowieka, a więc działalność człowieka - osoby. Stąd sport jawi się jako relacja osoby ludzkiej do jej ciała, polegająca - oddajmy tu głos św. Tomaszowi - na „uczynieniu go narzędziem działania cnoty"6. Akwinata bowiem nie zna angielskiego słowa ,sport”, jednak bardzo często wypowiada się na temat takiego odnoszenia się człowieka do swojego ciała, aby służyło ono dziełom cnoty?

Z uwagi na fakt, że wyraz ,sport” za czasów św. Tomasza nie był jeszcze znany, nie można żądać od niego definicji tego pojęcia. Niemniej mamy u Akwinaty szereg składników, z których możemy zbudować tę definicję. Tomasz bowiem nigdy nie wprowadza dowolnej definicji, ale przyjmując jakiś wyraz zgodnie z powszechnie przyjętym oznaczeniem, stara się po pierwsze wyodrębnić przedmioty, którym dana nazwa przysługuje, po wtóre zbadać, co zasadniczo jest wspólne im i tylko im oraz po trzecie, co jest wspólne im oraz innym przedmiotom, których potoczny język nie obejmuje tą nazwą, ale obejmuje jedne i drugie jakimś wspólnym, bardziej ogólnym wyrazem jako nazwą rodzaju, do którego jedne i drugie należą jako jego różne gatunki. W myśl tych reguł definiowania podanych przez Akwinatę prof. Feliks Wojciech Bednarski pisze, że można przyjąć za oczywiste, iż „sport nie jest jakąś rzeczą czy zbiorem rzeczy ani jakąkolwiek formą bezczynności, lecz zespołem pewnych czynności i to czynności ludzkich, odpowiednio uporządkowanych i skierowanych do określonego celu"s. Dalej na podstawie metafizycznych poglądów Akwinaty można ująć sport jako stricte ludzką przypadłość, pewnego rodzaju sprawność (habitus), rozumianą jako zespół czynności typowo ludzkich, wynikających z samych pierwocin natury ludzkiej, uporządkowanych przez rozum i skierowanych przez wolę, czasem nawet $\mathrm{z}$ wydatną pomocą uczuć, do określonego celu zgodnego z naturą człowieka._W takim ujęciu sport byłby według św. Tomasza zaspokojeniem pewnych potrzeb każdego człowieka wynikających z samej jego pierwotnej, wręcz instynktownej natury, gdyż

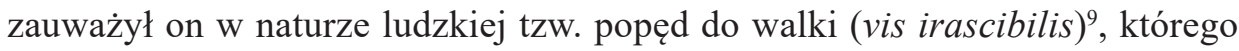
usprawnienie jest konieczne dla każdego rodzaju sportu. Albowiem to właśnie sport wyzwala w nas jakiś wewnętrzny i trudny w praktyce do opisania dynamizm tej żywiołowej siły, jaką jest ów popęd do walki o pewne, czasem nad wyraz trudne

\footnotetext{
A. Andrzejuk, Sport w ujęciu tomistycznym, w: Kościół a sport, red. Z. Dziubiński, SALOS, Warszawa 1995, s. 47.

6 Por. S. Th. I-II, q. 56, a. 4, ad. 2.

7 Por. A. Andrzejuk, dz. cyt., s. 48.

8 F. Bednarski, Sport $i$ wychowanie fizyczne w świetle etyki św. Tomasza z Akwinu, Veritas, Londyn 1962, s. 18.

9 Por. S. Th. I, q. 81, a. 2 c.
} 
do zdobycia wartości, a mianowicie, o jak najlepsze wyniki zmobilizowanych sprawności cielesnych i duchowych oraz o niedopuszczenie, względnie zniszczenie zła zagrażającego tak człowiekowi, jak i społeczeństwu ${ }^{10}$.

$\mathrm{Z}$ tego wynika, że istotne i zasadnicze dla każdego rodzaju sportu jest zdobycie jak najlepszych wyników usprawnienia nie tylko cielesnego, ale i duchowego. Nie można bowiem pokonać przeciwnika czy usunąć licznych przeszkód życiowych bez usprawnienia ducha woli walki kierowanego rozumem. Jedno bez drugiego nie może ani naturalnie działać, ani tym bardziej czegokolwiek osiągnąć. Ta jedność ma bowiem charakter dynamiczny i ustopniowany, co się przejawia w zróżnicowanym rozwoju potencjalnych możliwości cielesnych i duchowych. Ta też jedność leży u podłoża ścisłego związku między kulturą duchową a fizyczną człowieka, to znaczy zarówno w życiu jednostki, jak i w życiu społecznym. Odnosząc zaś te uwagi do sportu, można powiedzieć: rozwijanie przez cierpliwe i wytrwałe ćwiczenia, przez trud i wysiłek, możliwości ciała określające kulturę fizyczną człowieka, otwiera też drogę, a nawet więcej - dopomaga do wzrostu, do rozwoju jego kultury duchowej ${ }^{11}$. Stanisław Olejnik pisze: „Kulturę duchową, nie tylko fizyczną wzmacnia i ubogaca mądrze przeprowadzony a intensywny trening - zmagania się ze sobą, ze słabością ciała, z własnym lenistwem i wygodnictwem" ${ }^{2}$. Taka zaś sprawność ciała i ducha staje się równocześnie istotą wychowania i samowychowania sportowego, które to zagadnienie zostanie omówione w następnym paragrafie ${ }^{13}$.

\section{KULTURA FIZYCZNA W ŚWIETLE NADPRZYRODZONYM}

Po opracowaniu pierwszego w dziejach filozofii systematycznego traktatu o uczuciach oraz traktatu o sprawnościach, przystępuje Akwinata do fundamentu życia i wychowania nadprzyrodzonego, mianowicie do zagadnienia łaski, a następnie do trzech cnót boskich: wiary, nadziei i miłości, odnoszących się bezpośrednio do Boga jako ostatecznego celu życia ludzkiego. W życiu chrześcijańskim można tylko teoretycznie odróżniać porządek przyrodzony od porządku nadprzyrodzonego; w praktyce przyrodzona kultura chrześcijanina winna być całkowicie podporządkowana kulturze nadprzyrodzonej i nią oświecona. Zasada ta obowiązuje również w zakresie kultury fizycznej ${ }^{14}$.

\footnotetext{
10 Por. M. Mylik, dz. cyt., s. 98.

11 Por. S. Olejnik, Podstawowe założenia i główne przesłanki chrześcijańskiej etyki sportu, w: Kościót a sport, dz. cyt., s. 66.

12 Tamże, s. 47.

13 Por. M. Mylik, dz. cyt., s. 118.

14 Por. F. Bednarski, dz. cyt., s. 51.
} 
Dla każdego katolika powinno być rzeczą oczywistą, że we wszystkim, a więc także w trosce o kulturę ciała, należy kierować się światłem Objawienia Bożego, a więc światłem wiary, która powinna być busolą, wskazującą człowiekowi jego ostateczny cel i drogę wiodącą do niego. Wszystko w życiu człowieka powinno być temu zadaniu podporządkowane, gdyż inaczej życie to nie byłoby rozumne i sensowne. Wszak rozum żąda, by człowiek postępował zgodnie ze swym celem. Kultura ciała nie powinna również wymykać się z obowiązku tego podporząadkowania, gdyż z zakresu życia nadprzyrodzonego niczego nie można usuwać ani ze strony duszy, ani ze strony ciała. Stąd wypływa wniosek, że dla chrześcijanina także kultura ciała winna być wciągnięta w orbitę życia nadprzyrodzonego, uwzględniając przy swym urzeczywistnieniu zasady wiary i podporządkować się łasce Bożej ${ }^{15}$.

Niewątpliwie wypowiedzi niektórych sportowców świadczą o ich świadomej, pogłębionej wierze, wyniesionej z domu rodzinnego, rozwijanej w parafialnym oratorium oraz umiejętnym zharmonizowaniu sportowej aktywności z praktykowaniem wymagań wiary w życiu osobistym, rodzinnym i społecznym. Fabrico Lorieri, bramkarz z Roma Calcio, może być tu rzecznikiem wielu innych sportowych włoskich rozmówców ${ }^{16}$. Powszechnie zadziwia u sportowców-katolików żywe, wprost entuzjastyczne zaangażowanie $\mathrm{w}$ sport $\mathrm{z}$ równoczesną wyważoną jego oceną: szerokie spojrzenie na wielorakie funkcje sportu bez jednoczesnego jego absolutyzowania. Właśnie w wierze religijnej Daniel Masala, olimpijczyk w pentatlonie, prezydent Europejskiej Federacji Chrześcijańskich Atletów, dostrzega najskuteczniejszą gwarancję dla humanistycznego sportu ${ }^{17}$. Sportowcy często w swych wypowiedziach podkreślają pozytywną rolę wiary w trudnych okolicznościach życia. Są to doświadczenia tym cenniejsze, że stanowią wyznania bardzo osobiste, intymne. Służą one mądrą radą dla uprawiających sport. Na przykład przeżycie przedwczesnej śmierci ucznia przyczyniło się do większej dojrzałości duchowej Marka Paoliniego, doktora ekonomii, entuzjasty piłki siat-

15 Por. tamże, s. 52-53.

16 „Sport jest dla mnie pracą i posiada swoje znaczenie. Ale tym, co mi bardziej jest drogie, jest rodzina, którą założyłem i dla której żyję codziennie. Staram się dawać czysty obraz mojego zawodu i mojego stylu konfrontacji z życiem. Rozumiem, że przykłady pociągają. Prowadzę życie dostatecznie normalne i spokojne, usiłując działać zawsze lepiej. Ufam, że mogę być spokojny w sumieniu, jakkolwiek święci przebywają jedynie w niebie. Jestem człowiekiem głęboko wierzącym i mam dobre relacje z Bogiem. Staram się praktykować - o ile to możliwe - chodzić do kościoła. Niestety muszę grać w niedzielę i nie zawsze zdołam być obecny na mszy. Niekiedy brakuje mnie na niej, lecz nie czynię tego ze złej woli czy też zaniedbania. W każdym bądź razie modlę się do Boga często". Cyt. za: Messaggero di Sant'Antonio, wrzesień 1992, s. 87.

17 „Każdego dnia znajduję chwilę na rozmyślanie i modlitwę. Wizja religijna jest niezbędna do przekonania siebie do pewnych wartości, dziś niestety w wielu przypadkach jakby zagubionych". Cyt. za: J. Cygan, Wiara w życiu sportowców, w: Wiara a sport, SALOS, Warszawa 1999, s. 81. 
kowej, trenera ${ }^{18}$. W życiu sportowców momentem szczególnym bywa również wydarzenie radosne, jak np. wielki sukces, zwycięstwo, które przeżywane w świetle wiary, może być czynnikiem wzrostu duchowego, jak to było w przypadku Alberto Cova, biegacza i medalisty olimpijskiego ${ }^{19}$.

Wiara prowadzi do nadziei, bo taka jest nasza natura, że jeżeli coś przedstawi się naszemu rozumowi w postaci dobra, samorzutnie budzi się w nas pożądanie tego dobra. Pożądanie to jest właśnie nadzieją ${ }^{20}$. W chrześcijańskim ujęciu wychowania fizycznego nadzieja odgrywa istotną rolę, nadając naszym staraniom o ciało właściwe nastawienie. Jeżeli wiarę możemy porównać do drogowskazu i busoli, to nadzieję należałoby uznać za zwrotnicę, która kulturze, także fizycznej, nadaje właściwy kierunek. Nadzieja potrafi natchnąc synowską bojaźnią, aby troszcząc się o kulturę fizyczną, nie zaniedbywać kultury moralnej i nie zejść na bezdroża ${ }^{21}$. Dar bojaźni Bożej związany z cnotą nadziei udziela człowiekowi szczególnej delikatności i wysubtelnia wrażliwość jego sumienia, by w niczym, nawet najmniejszą plamką grzechu, nie zaciemnił swego stosunku do Boga. W dziedzinie kultury fizycznej bojaźń Boża stwarza coś najpiękniejszego, co można wyobrazić sobie w człowieku: anielstwo w sportowcu ${ }^{22}$.

Nadzieja ustrzeże nas zarówno od zwątpienia w sens życia i w pomoc Bożą, jak i od prób osiągnięcia ostatecznego celu życia poprzez nieuczciwe środki. Usprawniając nasze dążenie do Boga jako ostatecznego celu i szczęścia, nadzieja doskonali nas tym samym w dążeniu do również innych ideałów etycznych. Pamiętać trzeba jednak o tym, na co św. Tomasz tak często zwraca uwagę, że ideały tylko wówczas nas pociągają, jeśli potrafi się przedstawić je sobie w postaci dobra mającego dla nas urok i siłę. Jeśli ideały skojarzymy z tym, co ponętne i pociągające, $\mathrm{z}$ większym zapałem i z większą wytrwałością będziemy do nich

18 „Moim marzeniem jest widzieć innych szczęśliwymi i staram się ich czynić takimi. Jestem wierzący i praktykujący, nigdy nie spowodowałem kryzysu mojej wiary w Boga, który jest miłością (...). Usiłuję zrozumieć liczne wątpliwości i wahania młodych na płaszczyźnie religijnej. Jak można dać zdrowe ukierunkowanie życiu, nie mając żądnej pewności? W sporcie, jak i w życiu, nie znoszę przekleństwa, pod żadnym pozorem. W takich przypadkach poczuwam się do obowiązku interweniowania u grających. Wiele i często modlę się za powierzonych mi zawodników". Cyt. za: L. Gugliemoni, Dio in campo. Sport e fede. Con interviste a cento capioni sportive. Torino 1994, s. 147-215:

19 „Przedtem podczas imprezy nie potrafiłem myśleć o niczym ani się pomodlić. Po zwycięstwie natomiast poczułem się zobowiązany podziękować Komuś. Mój rozwój jako człowieka i sportowca niewątpliwie zależał od tego, com przeżywał w wieku chłopięcym, najpierw z rodziną: modlitwy, msze, katechizm, a następnie w okresie młodzieńczym w oratorium”. Cyt. za: E. Sparano, A. Cattaneo, Uomini Cristiani, b.m. Ed. Paoline, Cinisello Balsamo, 1990, s. 21-22

20 Por. M. Mróz, Człowiek w dynamizmie cnoty. Aktualność aretologii św. Tomasza z Akwinu w świetle pytania o podstawy moralności chrześcijańskiej, Wyższe Seminarium Duchowne, Toruń 2001, s. 546-555.

${ }^{21}$ Por. F. Bednarski, dz. cyt., s. 53.

22 Por. tamże, s. 54. 
zmierzali ${ }^{23}$. Kultura ciała dostarcza bardzo wiele takich właśnie pociągających wartości, zwłaszcza przyjemnościowych i działających na wrodzony nam popęd do trudów walki. Jeśli te wartości skojarzymy z najwyższym ideałem życia, kultura ciała stanie się dla nas bodźcem rozwoju nadprzyrodzonej kultury ${ }^{24}$.

Źródłem, motorem i celem kultury ciała oraz wszelkiego wychowania fizycznego powinna być uporządkowana, nadprzyrodzona miłość Boga, bliźniego i siebie samego. Miłość bowiem jest najwyższym prawem, królową, a równocześnie matką wszelkiej kultury, a więc także kultury ciała. Z tej miłości płyną konkretne implikacje w odniesieniu do sportu. Po pierwsze: nakazuje ona respektowanie godności każdego człowieka jako rozumnej i wolnej osoby; zakazuje tym samym jakiejkolwiek instrumentalizacji człowieka ze względu na jego uzdolnienia i osiągnięcia sportowe. Podmiotowość sportowca mogą naruszać organizatorzy imprez sportowych, biznesmeni i sponsorzy, trenerzy, lekarze, a także fanatyczni kibice. Po drugie: nadprzyrodzona miłość, której człowiek się poddaje, wyklucza takie dewiacje życia sportowego, jakimi są awantury i bójki w trakcie rozgrywek sportowych. Miłość nadprzyrodzona pozwala również dostrzec osoby, które znajdują się w ciężkiej sytuacji życiowej. To ona sprawia, że osoby starsze, chore, niedołężne czy niepełnosprawne również mają możliwość aktywnego uczestniczenia w sporcie, oczywiście w miarę swoich możliwości. Właściwie pojęty sport nie może być przywilejem wyłącznie osób młodych i zdrowych, ale jest prawem każdego człowieka ${ }^{25}$.

Istnieje paląca potrzeba stworzenia sportowej cywilizacji miłości, w której busolą aktywności ludzi sportu będą: sprawiedliwość, prawda, dobro, piękno i otwarcie na drugiego człowieka. Wspólna praca na gruncie sportu potrzebuje idei naczelnej, fundamentalnej wartości, która nadałaby sens i połączyła w jedną całość pracę sportowców, trenerów, działaczy, lekarzy i sponsorów. Czy zatem istnieje jakaś inna idea, inna wartość lub inne światło, które byłoby w stanie nadać sens pracy sportowej wszystkich ludzi sportu? Otóż miłość jest tą siłą, która nie narzuca się człowiekowi z zewnątrz w postaci regulaminów, przepisów i nakazów, lecz rodzi się w jego wnętrzu, w jego sercu jako jego najbardziej wewnętrzna własność. Idzie tylko o to, aby ludzie sportu pozwolili się jej narodzić i by umieli nią nasycić swoją wrażliwość, swoje myślenie i działanie na basenie, w siłowni, na stadionie oraz hali sportowej ${ }^{26}$. Podczas przemówienia w Sopocie Jan Paweł II wyraźnie mówił, że niczego nie ma bez miłości: nie ma sportu bez miłości i każdej innej dziedziny życia. „Nie ma solidarności bez miłości. Więcej, nie ma

23 Por. M. Mróz, dz. cyt., s. 546-555.

24 Por. F. Bednarski, dz. cyt., s. 54.

25 Por. S. Kowalczyk, Elementy filozofii i teologii sportu, Towarzystwo Naukowe KUL, Lublin 2002, s. 198.

26 Por. Z. Dziubiński, Przesłanie Ojca Świętego Jana Pawła II do świata sportu, w: Sport na przetomie tysiacleci: szanse i nadzieje, red. Z. Dziubiński, SALOS, Warszawa 2000, s. 68. 
szczęścia, nie ma przyszłości człowieka i narodu bez miłości, nie ma rodziny bez miłości (...) Tej miłości, która przebacza, choć nie zapomina, jest wrażliwa, nie szuka swego, pragnie dobra innych, miłości, która służy, zapomina o sobie i jest gotowa do wspaniałomyślnego dawania"27.

Pozostając na płaszczyźnie życia nadprzyrodzonego, nie sposób nie odnieść się do Dziesięciu Przykazań. Św. Tomasz mówi: „Trzy z nich dotyczą miłości Boga, a siedem miłości bliźniego" ${ }^{28}$. Pierwsze trzy przykazania Dekalogu mogą obowiązywać także ludzi niewierzących w tym sensie, że stanowią przestrogę przed absolutyzacją sportu jako najważniejszego celu życia. Dekalog jest logiczną konsekwencją personalizmu, chroni bowiem godność osoby ludzkiej i należne jej prawa. Przypomina człowiekowi, jak powinno wyglądać jego życie, jeżeli chce uzyskać zbawienie ${ }^{29}$. Te wszystkie słowa $\mathrm{z}$ kamiennych tablic dotyczą również sportowca, który ma widzieć kulturę fizyczną w świetle nadprzyrodzonym. Choć większość przykazań ma sformułowanie negatywne, w formie zakazów, to jednak ich treściowe znaczenie jest zawsze pozytywne. Wszystkie przykazania chronią podstawowe wartości człowieka: życie, zdrowie, godność osobistą, małżeństwo i rodzinę, własność jako podstawę codziennej egzystencji oraz wartości moralne i religijne ${ }^{30}$.

Odnosząc komentarz św. Tomasza do pierwszego przykazania do świata sportu można powiedzieć, że równiez sport nie powinien stać się bożyszczem, idolem, wartością najwyższą i absolutną. A tak właśnie często się dzieje, gdyż w niektórych formach aktywności sportowej lekceważy się zdrowie, naraża życie, lekceważy dobro osoby czy dobro wspólne. Kultura fizyczna nie powinna prowadzić do atrofii kultury duchowej - w tym moralnej i religijnej. Postawy ludzi związanych ze sportem, częściej kibiców aniżeli samych sportowców, bywają jawną deformacją pierwotnego i właściwego sensu takiej aktywności człowieka. Kultura ciała ludzkiego przekształca się w rodzaj kultu ciała: stadiony, baseny, boiska czy korty są miejscem parareligijnego kultu herosów sportowych, a rekordomania staje się obsesją hałaśliwych tłumów, sławiących zwycięzców poszczególnych dyscyplin sportu. Pierwsze przykazanie przypomina ludziom wierzącym, że sport nie może zostać uznany za dobro najwyższe i absolutne w życiu człowieka. Nie może on stanowić surogatu religii ${ }^{31}$.

Drugie przykazanie bezpośrednio postuluje, aby w języku człowieka wierzącego i każdego człowieka respektującego wymogi kultury, w tym sportowców, nie było słów bluźnierczych skierowanych przeciw Bogu. Można to przykazanie interpretować w szerszym sensie, mianowicie jako apel o kulturę języka. Znaną

27 Tamże.

28 Tomasz z Akwinu, Wykład pacierza, przekł. K. Suszyło, W drodze, Poznań, s. 151.

29 Por. S. Kowalczyk, dz. cyt., s. 197.

30 Por. tamże, s. 198.

31 Por. Tomasz z Akwinu, Wyktad, dz. cyt., s. 151-155. 
jest rzeczą, że podczas imprez sportowych takiej właśnie kultury często brakuje, a wulgarność używanego słownictwa bywa wstępem do toczonych tam bójek ${ }^{32}$.

Imprezy sportowe odbywają się najczęściej w dni świąteczne albo dni wolne od pracy poprzedzające święta. Z tego względu szczególnie ważne jest dla ludzi wierzących trzecie przykazanie. Przykazanie to niesie określone zobowiązania dla organizatorów imprez sportowych, jak i samych sportowców. Ci pierwsi, kierując różnego typu obozami przygotowawczymi, treningami i układając kalendarz zawodów sportowych, powinni umożliwiać swym podopiecznym udział w życiu religijnym. W okresie reżimu komunistycznego działo się zwykle odwrotnie: dla młodzieży i dzieci (nie mówiąc o zawodach sportowych) organizowano imprezy sportowe zwykle w niedzielę przed południem, co odciągało młodych ludzi od udziału we Mszy św. albo je nawet uniemożliwiało ${ }^{33}$. Obecnie sytuacja zmieniła się w sposób istotny, czego potwierdzeniem jest m.in. obecność duszpasterzy w środowiskach sportowych. Modlitwa jest formą wewnętrznej koncentracji, która jest niezbędna w humanistycznie pojmowanym sporcie. Człowiek jest psychofizyczną całością i dlatego aktywność zewnętrzna - sport - wymaga również aktywności wewnętrznej, którą jest właśnie modlitwa. W życiu wierzącego sportowca fałszywa jest alternatywa: impreza sportowa lub modlitwa, ponieważ jedno i drugie jest potrzebne do harmonijnego oraz pełnego rozwoju jego osobowości ${ }^{34}$.

Czwarte przykazanie ma na celu ochronę dobra wspólnego rodziny. Młodzi sportowcy planują założenie rodziny, starsi zwykle już ją mają. Długotrwałe treningi, obozy szkoleniowe i częste wyjazdy na imprezy sportowe niewątpliwie utrudniają normalne życie rodzinne, tj. kontakt między małżonkami oraz między rodzicami i dziećmi. Czwarte przykazanie jest więc niezwykle aktualne w życiu zawodowych sportowców, którzy wykonując swoje obowiązki, nie powinni zaniedbywać współmałżonka, dzieci czy potrzebujących rodziców. Przede wszystkim sport nie powinien prowadzić do rozerwania spoistości rodziny czy jej rozpadu. Nie może on także stać się dla kobiet-sportsmenek powodem do rezygnacji z macierzyństwa, bez którego trudno mówić o normalnej rodzinie ${ }^{35}$.

Przykazanie „Nie zabijaj” stoi na straży życia i zdrowia. Często używany jest slogan ,sport to zdrowie”. Tak powinno być i zwykle tak bywa w sporcie amatorskim i rehabilitacyjnym. Sprawa się komplikuje w sporcie wyczynowym, gdzie pojawia się wiele patologii zagrażających zdrowiu czy nawet życiu zawodnika. Niemniej występujące zagrożenia związane ze sportem wyczynowym nie dyskredytują sportu jako takiego. Są one jednak przestrogą, aby aktywność sportowa była organizowana i realizowana w sposób odpowiedzialny i zgodny z etyką.

32 Por. S. Kowalczyk, dz. cyt., s. 199.

33 Por. tamże.

34 Por. Episkopat Włoch, List pasterski „Sport a życie chrześcijańskie”, w: Sport na przełomie tysiącleci: szanse i nadzieje, dz. cyt. s. 200.

35 Por. S. Kowalczyk, dz. cyt., s. 200. 
Celem człowieka nie może być zwycięstwo i ustanowienie kolejnego rekordu za cenę utraty zdrowia czy z narażeniem się na niebezpieczeństwo utraty - aktualnie lub w bliskiej perspektywie - życia ${ }^{36}$. W odniesieniu do zdrowia imperatyw moralny „nie zabijaj” nakazuje postawy prozdrowotne, występując przeciwko wszystkiemu, co zdrowie degraduje i niweczy. W obrębie tych spraw znajduje się niewłaściwy tryb życia i odżywiania się oraz niefrasobliwy stosunek do używek. W przeciwieństwie do tego szeroko pojęte postawy prozdrowotne są wypełnieniem piątego przykazania. Imperatyw moralny „nie zabijaj” pozostaje na usługach zdrowia i chrześcijańskich wymiarów sportu oraz przeciwdziałań wobec wszelkich patologii społecznych niszczących zdrowie ${ }^{37}$.

„Po zabronieniu zabójstwa Bóg zabrania cudzołóstwa i słusznie, bo mąż i żona są jakby jednym ciałem. 'Będą dwoje jednym ciałem' - mówi Bóg w Księdze Rodzaju (2,24). Stąd po krzywdzie, jaką można wyrządzić osobie, nie ma większej niż ta, którą wyrządza się komuś, kto jest z tą osobą najściślej związany"38. Z przykazaniem „Nie cudzołóż” wiąże się ściśle dziewiąte: „Nie pożądaj żony bliźniego swego". Bezpośrednio nakazują one respektowanie godności człowieka, a w dalszej perspektywie ochronę dobra małżeństwa i rodziny będących tym środowiskiem społecznym, w którym zapoczątkowuje się życie człowieka i możliwe jest jego najbardziej harmonijne wychowanie. Aktywność sportowa nie powinna w niczym kolidować ze wspomnianymi nakazami moralnymi, dlatego moralnie naganne są takie zjawiska, jak ekshibicjonizm, epatowanie nagością, wulgarność języka, propagowanie hedonizmu i rozwiązłości, seksualne wykorzystanie zawodniczek czy zawodników. To ostatnie miało miejsce w wypadku dopingu ciążowego. Miłość jest prawem człowieka i podstawą rodziny, ale nie należy jej mylić z rozpasaną seksualnością ${ }^{39}$.

Tak św. Tomasz wprowadza w treść siódmego przykazania: „Pan w swoim Prawie zabronił przede wszystkim wyrządzania krzywdy bliźniemu. Najpierw w odniesieniu do jego osoby i stąd mamy przykazanie: 'Nie zabijaj'. Następnie do osoby najbliżej z nim związanej: 'Nie cudzołóż'. I na trzecim miejscu do jego rzeczy: 'Nie kradnij'” ${ }^{40}$. Bezpośrednio z nim związane jest przykazanie: „Nie pożądaj żadnej rzeczy bliźniego swego". Mają one na celu ochronę własności, bez której nie jest możliwa spokojna egzystencja człowieka i jego rodziny. Możliwe jest naruszenie tych przykazań już w sporcie amatorskim, kiedy jest on powodem zaniedbywania podstawowych obowiązków, np. nauki przez młodzież czy pracy zawodowej przez osoby dorosłe. Sport rekreacyjny ma przywrócić człowiekowi zdolność do intensywnej pracy, nie powinien więc być jej rywalem. Bardziej

36 Por. tamże, s. 201.

37 Por. Z. Łysko, Sport i zdrowie, w: Z. Dziubiński, Wiara a sport, dz. cyt., s. 49.

38 Tomasz z Akwinu, Wyktad, dz. cyt., s. 183.

39 Por. S. Kowalczyk, dz. cyt., s. 202.

40 Tomasz z Akwinu, Wyktad, dz. cyt., s. 187-188. 
częste i groźne są wykroczenia przeciw siódmemu przykazaniu w sporcie zawodowym. $Z$ etyką kolidują nieuczciwe sposoby zarabiania pieniędzy, a tak się dzieje wówczas, kiedy mają miejsce różnego typu oszustwa, stosowanie dopingu, przekupywanie zawodników, „kupowanie” meczów piłki nożnej itp. Grzechem przeciw temu przykazaniu jest również wandalizm pseudokibiców, którzy niszczą wyposażenie stadionów, ich otoczenie, środki lokomocji i to wszystko, co napotkają na swej drodze po zakończeniu imprezy sportowej ${ }^{41}$.

Dalej w swoim komentarzu św. Tomasz pisze: „Nakazał Pan, by nikt nie wyrządzał swojemu bliźniemu krzywdy czynem. Teraz zabrania czynić tego również słowem i dlatego czytamy: 'Nie mów fałszywego świadectwa przeciw bliźniemu swemu'. Może to mieć miejsce w sądzie albo zwykłej mowie"42. Ludziom sportu powierzona została szczególna odpowiedzialność za prawdę - dążenie do niej, jej obronę i życie według niej. Sport pozbawiony prawdy, zafałszowany i oszukańczy jest swoim zaprzeczeniem, nie zasługuje na miano działalności kulturowej ${ }^{43}$. Ósme przykazanie chroni prawdę, która jest fundamentalnym prawem całego życia społecznego. Przeciw prawdzie można grzeszyć na terenie sportu w różny sposób, np. przez stronnicze i niesprawiedliwe decyzje sędziów, stosowanie dopingu fałszującego wyniki sportowej rywalizacji, „kupowanie” oczekiwanych wyników imprez sportowych lub zastraszanie zawodników z motywów politycznych. Naruszeniem ósmego przykazania jest także stwarzanie klimatu zacietrzewienia czy wręcz nienawiści pomiędzy rywalizującymi ze sobą drużynami sportowymi oraz ich kibicami ${ }^{44}$.

\section{SPORT A CNOTY KARDYNALNE}

Cnoty teologiczne: wiara, nadzieja i miłość usprawniają człowieka w stosunku do Pana Boga jako ostatecznego i nadprzyrodzonego celu życia ludzkiego. Wszystkie inne sprawności doskonalą nas w stosunku do środków służących do osiągnięcia tego celu. Ponieważ cel jest miarą środków i sprawdzianem ich wartości, zadaniem wszystkich innych cnót będzie usprawnić człowieka w używaniu tych środków zgodnie z ich celem. Cnoty te nazywamy obyczajowymi. Jedne z nich usprawniają rozum, inne zaś wolę, a jeszcze inne popęd do walki i popęd do przyjemności. Spośród cnót obyczajowych zasadnicze nazywamy

${ }^{41}$ Por. S. Kowalczyk, dz. cyt., s. 202.

42 Tomasz z Akwinu, Wyktad, dz. cyt., s. 191-192.

43 Por. Z. Dziubiński, Przestanie, dz. cyt., s. 64.

44 Por. S. Kowalczyk, dz. cyt., s. 203. 
kardynalnymi, zaliczając do nich: roztropność, sprawiedliwość, męstwo i umiarkowanie ${ }^{45}$. Nieocenioną rolę $\mathrm{w}$ ich kształtowaniu odgrywa sport.

Cnota roztropności jest „matką cnót” i winna towarzyszyć przez całe życie człowiekowi zwłaszcza tam, gdzie realizacja pewnych celów wnika w istotę ludzką i ma znaczący wpływ na jej rozwój ${ }^{46}$. Taką dziedziną życia jest z pewnością sport, w ramach którego człowiek zmierza do przekroczenia dotychczasowych granic ludzkich możliwości (w przypadku ustanawiania rekordów świata), do przewyższenia tych możliwości, którymi dysponuje przeciwnik bądź też do przekraczania swoich możliwości w pokonywaniu naturalnych przeszkód (np. w alpinizmie, samotniczym żeglarstwie, wyprawach polarnych itp.). We wszystkich działaniach sportowych winna być zachowana cnota roztropności, nie tylko podczas zawodów, ale także w okresie przygotowawczym ${ }^{47}$. Mówiąc o roztropności, św. Tomasz zwraca uwagę na konieczność usprawniania naszych uzdolnień zmysłowych, koniecznych do takich cnót, jak inteligencja, przytomność umysłu, oględność, przezorność, spostrzegawczość, wchodzących w skład roztropności jako jej zasadnicze warunki ${ }^{48}$. Oczywiście wychowanie fizyczne może służyć szczególną pomocą dla kultury umysłowej i moralnej. I tak dla przykładu - zabawy i gry ruchowe, rozwijając celowość i szybkość reakcji zmysłów przyczyniają się do usprawnienia człowieka w spostrzegawczość i przytomność umysłu. Większość ludzi, chociaż rozporządza sprawnymi zmysłami, nie umie się dobrze nimi posługiwać ani ich należycie wykorzystać. Stąd spostrzegawczość ich jest słaba. Naturalne uzdolnienia wskutek tego bywają często zamrożonym kapitałem, który nie przynosi żadnego pożytku. Słaba spostrzegawczość znowu utrudnia bystrość, zaradność, przytomność umysłu, a tym samym roztropność, zwłaszcza w chwilach trudnych i niezwykłych. Systematycznie przeprowadzane ćwiczenia, jak jazda na rowerze, turystyka, narciarstwo, mogą przyczynić się do rozwoju kultury moralnej, jeśli rozwijają spostrzegawczość, przytomność umysłu i zaradność 49 .

Uprawiając sport, nie można zapomnieć, że chodzi o takie usprawnienie człowieka, by ani sobie, ani innym nie zaszkodził na zdrowiu, mieniu, dobrej sławie i życiu rodzinnym, lecz sumiennie spełniał wszystkie swe obowiązki względem

45 Por. M. Graczyk., Udziat sportu w kształtowaniu moralnych doskonatości człowieka, w: Kościót a sport, dz. cyt., s. 74.

46 Por. M. Śniadecki, O fizycznym wychowaniu dzieci, Ossolineum, Wrocław 1956, s. 55.

47 „Widzimy bowiem, że sprawność ciała osłabia się na skutek nadmiaru gimnastyki, czyli pewnych ćwiczeń cielesnych... gdyż z powodu zbyt meczącej pracy jego naturalne siły ulegają wyczerpaniu. Tak samo brak tychże ćwiczeń, gdyż wskutek tego członki stają się wiotkie i niezdolne do trudu. Podobnie zdrowie psuje się, gdy ktoś przyjmuje albo zbyt wiele, albo zbyt mało pokarmu czy napoju, a nie tyle ile trzeba. Lecz gdy używa się tych ćwiczeń, pokarmu czy napoju podług właściwej miary, zdrowie wzmacnia się i zachowuje". Cyt. za: Tomasz z Akwinu, Komentarz do Etyki Nikomachejskiej Arystotelesa, II, nr 261.

48 Por. S. Th., II-II, q. 49.

49 Por. F. Bednarski, dz. cyt., s. 63. 
Boga, ojczyzny i wszystkich ludzi, przestrzegając prawdomówności i szczerości, karności i posłuszeństwa, wdzięczności i uprzejmości, a mówiąc jednym słowem sprawiedliwości ${ }^{50}$. Sprawiedliwość jest drugą cnotą kardynalną, która ,wprowadza porządek w sprawach dotyczących stosunków jednych ludzi do drugich" ${ }^{\prime 51}$. Sprawiedliwość, rozumiana jako sprawność doskonaląca naszą wolę w oddawaniu każdemu tego, co się mu należy, posiada szczególne znaczenie dla sportu. Posiadanie tej cnoty w jakimś stopniu strzeże sportowca przed ćwiczeniami grożącymi utratą zdrowia lub życia, które narażać wolno tylko wówczas, gdy tego wymaga konieczność społeczna ${ }^{52}$.

W tym miejscu warto zaznaczyć, że kultura fizyczna, rozwijając w obywatelach solidarność i poczucie życia społecznego, przygotowuje ich tym samym do ofiarnej służby dla ojczyzny. Każdy członek drużyny uczy się przecież podporządkowywać swoje zachcianki i ambicje dobru zespołu oraz pomagać w grze nawet tym kolegom, do których czuje on niechęć, skoro tego domaga się taktyka gry ${ }^{53}$. Dzięki zabawom i ćwiczeniom z zakresu kultury fizycznej człowiek wyzbywa się skłonności antyspołecznych. Dzieci zazwyczaj mają silnie wykształconą wolę walki, która niejednokrotnie przybiera charakter antyspołeczny. Nie należy jej w dzieciach niszczyć, gdyż ma ona ważne znaczenie w życiu, należy tylko kierować ją na odpowiednie tory, dając jej właściwe ujście. Właśnie ćwiczenia fizyczne, zwłaszcza zespołowe gry kontaktowe o charakterze walki, spełniają to zadanie, pozwalając na nieszkodliwe, a raczej pożyteczne wyładowanie sił bez szkody dla drugich i samego siebie.

Jednym z głównych zadań ćwiczeń sportowych jest pomoc w usprawnianiu wrodzonego człowiekowi popędu do walki przez opanowanie związanych z nim uczuć, a zwłaszcza odwagi, bojaźni i szlachetnej ambicji tak, by wytrwale i cierpliwie spełniał swoje obowiązki mimo największych trudności, nieszczęść i przeszkód, nawet w niebezpieczeństwie śmierci. To opanowanie popędu do walki wraz z uczuciami z nim związanymi, a mianowicie odwagi, bojaźni i ambicji, jest zadaniem męstwa i kilku cnót, ${ }_{2}$ przede wszystkim wielkoduszności ${ }^{54}$. Uprawianie sportu, dążenie do osiągania określonych przez siebie wyników daje okazje do doskonalenia się w takich cnotach jak cierpliwość, stałość, wytrwałości i długomyślność, które św. Tomasz ściśle wiąże z męstwem ${ }^{55}$. Niejednokrotnie bowiem uprawiana dyscyplina wymaga pokonania nudy na jednostajnej i nieciekawej, a często i długiej drodze treningu do wyznaczonego celu sportowego.

\footnotetext{
50 Por. M. Graczyk, dz. cyt., s. 81.

51 Por. S. Th., II-II, q. 57, a. 1c.

52 Por. F. Bednarski, dz. cyt. s. 67-68.

53 Por. M. Graczyk, dz. cyt., s. 82.

54 Por. S. Th., II-II q. 123 i 129.

55 Por. tamże, q. 136 I 137.
} 
Wielkoduszność ma szczególnie doniosłe znaczenie dla wychowania fizycznego, ponieważ gry i różnego rodzaju sporty w bardzo silnym stopniu rozbudzają ambicję rekordową. O ile brak zdrowej ambicji nie jest zaletą, ponieważ usuwa z życia jeden z ważnych jego bodźców, to wygórowana ambicja jest wadą. Wielkoduszność jawi się w tym kontekście jako sprawność, która usprawnia nas w opanowaniu zdrowej ambicji tak, byśmy mogli dążyć do jak największych ideałów bez względu na trudności. Różni się ona od męstwa i pozostałych cnót z jego orszaku tym, że przedmiotem jej nie jest zło, które człowiek pragnie zwyciężyć, ale dobro, zwłaszcza honor, które chce zdobyćs ${ }^{56}$.

Kultura fizyczna kształtuje w człowieku kolejną cnotę kardynalną - umiarkowanie, czyli panowanie nad popędem do przyjemności związanych z czynnościami ciała, zwłaszcza w zakresie odżywiania, ruchu i spoczynku tak, by tych przyjemności używać wtedy, gdy należy tyle, ile należy i tak, jak należy: ani za mało, ani za wiele. Wydaje się, że wszystkie dyscypliny sportowe posiadają duże znaczenie w kształtowaniu postawy umiaru. Wzmacniają one bowiem kontrolę duchową nad ciałem i jego potrzebami, przede wszystkim zaś nad tymi tendencjami, które działają rozprzęgająco. Sportowiec jest nieustannie wzywany do zapierania się samego siebie, w tym sensie, że, np. przestrzega ustalonej diety po to, aby uniknąć niepowodzeń zależnych od nieodpowiedniej postury fizycznej. Wydaje się więc, że jeśli ktoś przyzwyczaił się znosić głód, pragnienie, chłód, różne niewygody i zmęczenie, ten z większą łatwością będzie umiał oprzeć się pokusom używania narkotyków czy pokusom płciowym, szczególnie wówczas, kiedy domagać się będą tego pobudki moralne, estetyczne, społeczne i umysłowe. $Z$ tych właśnie względów wychowanie fizyczne jest w samej rzeczy jednym z najskuteczniejszych sposobów właściwego opanowania skłonności do przyjemności w zakresie odżywiania się i przekazywania życia ${ }^{57}$.

Sport dobrze uprawiany przygotowuje młodzież do przyszłych zadań. Przez wzmacnianie sił fizycznych rozwija jej zapał do podejmowania nawet trudnych przedsięwzięć. Oczywiście, przeniesienie takich zalet, jak poczucie solidarności, karności, posłuszeństwa z jednego terenu, np. boiska sportowego, na drugi, np. do szkoły, nie zawsze następuje od razu. A w ogóle nie nastąpi wtedy, jeżeli z ćwiczeniami z zakresu kultury fizycznej nie połączy się konkretnych ideałów kultury moralnej. Nastąpi to wtedy, gdy wychowawca chce i potrafi doskonalić także moralną kulturę swoich wychowanków, których zaprawia do kultury fizycznej ${ }^{58}$.

\footnotetext{
56 Por. A. Potocki, Sport i cnoty moralne (refleksje po lekturze św. Tomasza), w: Wiara a sport, dz. cyt., s. 182.

57 Por. Z. Dziubiński, Aretologia, dz. cyt., s. 341.

58 Por. A. Potocki, dz. cyt., s. 182.
} 


\section{ZAKOŃCZENIE}

Sport, właściwie pokierowany, odgrywa ważną rolę w kształtowaniu doskonałości moralnej człowieka. Wynika to z jego chrześcijańskiej wizji, w której podkreśla się konsubstancjalną jedność między ciałem i duchem. W konsekwencji doskonalenie ciała, co jest pierwszorzędnym celem ćwiczeń sportowych, ma pewien wpływ na rozwój życia duchowego człowieka. Wyraźnie dostrzega się to w analizie związków, jakie zachodzą między uprawianiem sportu a cnotami teologalnymi, jak również w odniesieniu do cnót kardynalnych. Tak więc sport to nie tylko wyłącznie rozwój fizyczny. Poprawnie pojmowany, na straży czystości którego stoi Dekalog, ożywia dynamikę życia nadprzyrodzonego człowieka. Rozwija jego charakter, czyni go odważnym w chwili zwycięstwa i porażki. Pomaga też człowiekowi w wypełnianiu tego celu, któremu wszystkie inne są podporządkowane, a którym jest służba i oddawanie chwały samemu Stwórcy.

\section{Bibliografia}

Bednarski F., Sport i wychowanie fizyczne w świetle etyki św. Tomasza z Akwinu, Veritas, Londyn 1962.

Dziubiński Z., Antropologia sportu, SALOS, Warszawa 2002.

Dziubiński Z., Kościót a sport, SALOS, Warszawa 1995.

Dziubiński Z., Społeczny wymiar sportu, SALOS, Warszawa 2003.

Dziubiński Z., Wiara a sport, SALOS, Warszawa 1999.

Dziubiński Z., Sport na przełomie tysiacleci: szanse i nadzieje, SALOS, Warszawa 2000.

Kowalczyk S., Elementy filozofii i teologii sportu, Towarzystwo Naukowe KUL, Lublin 2002.

Krawczyk Z., Encyklopedia kultury polskiej XX wieku. Kultura fizyczna-sport, Instytut Kultury, Warszawa 1997.

Mróz M., Człowiek w dynamizmie cnoty. Aktualność aretologii św. Tomasza z Akwinu w świetle pytania o podstawy moralności chrześcijańskiej, Wyższe Seminarium Duchowne, Toruń 2001.

Śniadecki M., O fizycznym wychowaniu dzieci, Ossolineum, Wrocław 1956.

Thomae Aquinatis, Summa Theologiae, w: Opera omnia, iussu Leonis XIII P.M. edita, cura et studio Fratrum Praedicatorum, Typografia Polyglotta, Romae 1889-1906. (wyd. pol.: Św. Tomasz z Akwinu, Suma teologiczna, thum. i oprac. F. W. Bednarski, St. Bełch, P. Bełch, A. Głażewski, R. Kostecki, St. Piotrowski, Londyn 1963-1998.

Tomasz z Akwinu, Wykład pacierza, przekł. K. Suszyło, W drodze, Poznań 2005. 